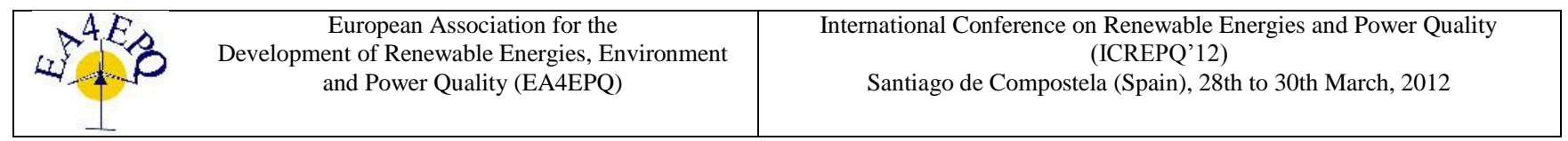

\title{
Energy production estimating of photovoltaic systems
}

\author{
G. Ádám, K. Baksai-Szabó and P. Kiss \\ Department of Electrical Engineering \\ Budapest University of Technology and Economics \\ Egry József street 18 V1 bdg 4th floor, H-1111 Budapest (Hungary)
}

Phone: +36 1463 2999, e-mail: adamgabor86@gmail.com, baksai.szabo.kristof@gmail.com, kiss.peter@vet.bme.hu

\begin{abstract}
There are several freeware programs for energy production estimation of PV systems. Some are quite simple, while others take a lot of input parameters to give the best estimation. Our program has been written in MATLAB environment, and has a great advantage over other commercial software as it calculates more output variables, furthermore with hourly resolution. The results are not fully satisfying yet, so we'll make further developments on it.
\end{abstract}

\section{Key words}

Photovoltaic system, energy production, electrical energy balance, solar inverter, MATLAB, computer simulation

\section{Introduction}

Solar Decathlon is an international competition between universities, which has been arranged since 2002 in the USA. The first competition in Europe called Solar Decathlon Europe (SDE) was held in 2010 in Madrid, the further editions are planned also with a two-year period. [1]

Its main goal is promoting solar architecture, and supporting green technologies on social and market side. Participating teams have to design and construct a small, energy-efficient, light structure house for two-person, which utilises solar energy.

The team of the Budapest University of Technology and Economics (BME) has been qualified successfully to the best 20, and now we have half a year left to construct the house in September 2012 in Madrid.

As the members of the electrical team we have to design the PV system and the electrical system of the house. We also have to make an energy balance estimation and for this we have to calculate the expected energy production of the PV system.
There are several freeware programs for modelling the energy production of the PV systems. These are calculating only the best case daily production values and they don't give many output data which would be important for us. So we decided to develop our own program, which can estimate energy production on hourly or 6-minutes base. Its output parameters are not only produced energy, but also several other important parameters. The development was made in MATLAB environment, as big data sets had to be processed, and the MATLAB is designed especially for matrix calculations.

\section{The modelled PV system}

The floor space of our house is $140 \mathrm{~m}^{2}$ including the terrace, and the area of the house roof is $60 \mathrm{~m}^{2}$. On the southern side of the terrace there is a quite thick wall outside, mainly for the summer kitchen and the building engineering. The PV modules are located on the house roof, the wall roof and the wall facade - with 1-1 solar inverter for each PV field. The tilt angle of both roofs is $6.5^{\circ}$.
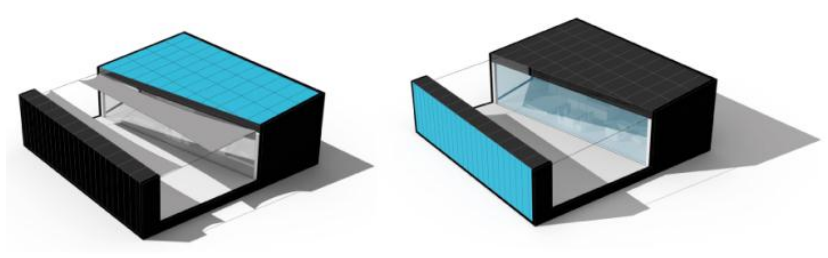

Fig. 1: The Odoo house

All PV modules are from the Hungarian modulemanufacturer Korax, type KS-245B. It consists of monocrystalline cells, and has a nominal peak power of $245 \mathrm{~W}$. The module efficiency is $15.1 \%$, the temperaturedependency of its power is $-0.47 \% /{ }^{\circ} \mathrm{C}$.

The PV field on the house roof has 3 strings, each with 11 modules in series, $8.085 \mathrm{~kW}_{\mathrm{p}}$ altogether. On the wall roof there are $1.715 \mathrm{~kW}_{\mathrm{p}}$, on the wall facade $3.675 \mathrm{~kW}_{\mathrm{p}}$ 
PV modules, so the full size of the grid-connected system is $13.475 \mathrm{~kW}_{\mathrm{p}}$.

As the three PV fields are different both in size and tilt angle, we've chosen separate inverters for each [5]:

- house roof: SMA Sunny Mini Central 6000A

- $\quad$ wall roof: SMA Sunny Boy 1200

- wall facade: SMA Sunny Boy 2500HF

\section{Program functioning}

\section{A. Calculation method}

The calculation is based on a simple physical law, according to which the power of a solar cell depends on two factors: the radiation intensity on the PV cell surface and the temperature of the cell. The actual power varies directly with the former factor, and inversely with the latter, compared to the nominal power.

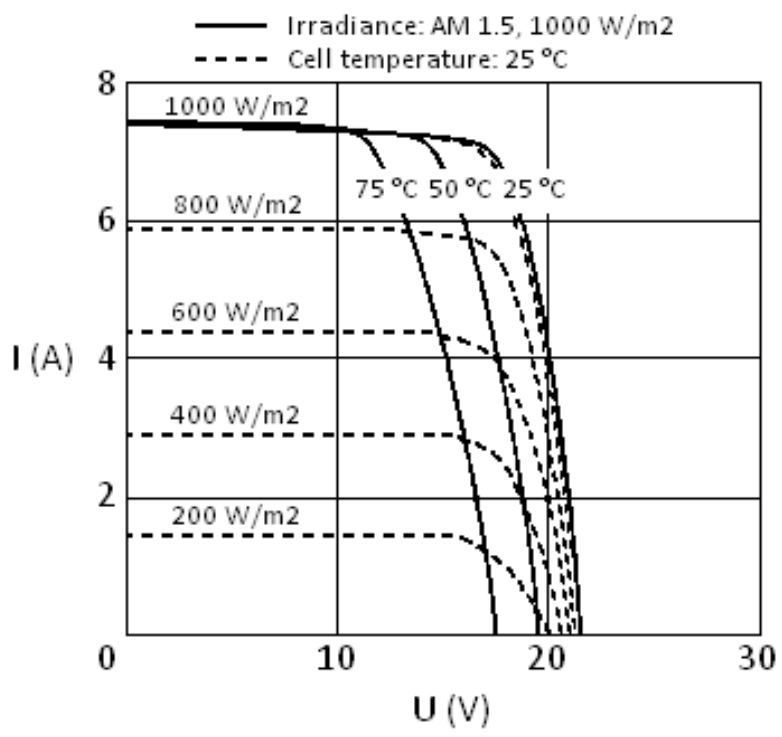

Fig. 2. Current vs. voltage characteristics of a PV cell

Module manufacturers specify the nominal power under Standard Test Conditions (STC) which includes AM 1.5 air mass, $1000 \mathrm{~W} / \mathrm{m}^{2}$ perpendicularly incident radiation and $25^{\circ} \mathrm{C}$ cell temperature.

$$
\begin{gathered}
\mathrm{P}_{A C}=\left(\mathrm{P}_{\text {nominal }} \cdot\left(1+\left(\mathrm{T}_{\text {cell }}-25\left[{ }^{\circ} \mathrm{C}\right]\right) \cdot \frac{\mathrm{dP}}{100}\right) .\right. \\
\left.\frac{\mathrm{S}}{1000\left[\mathrm{~W} / \mathrm{m}^{2}\right]}-\mathrm{P}_{\text {cable }}\right) \cdot \eta_{\text {inv }}(1)
\end{gathered}
$$

The formula for the AC side output power of the inverter is shown above [6]. $\mathrm{P}_{\text {nominal }}[\mathrm{W}]$ is the nominal power of the $\mathrm{PV}$ module, $\mathrm{S}\left[\mathrm{W} / \mathrm{m}^{2}\right]$ is the irradiation on the cell surface, and $\mathrm{dP}\left[\% /{ }^{\circ} \mathrm{C}\right]$ is the temperature coefficient of the cell. This latter is a negative number which denotes the change of the output power if the cell temperature changes by $1{ }^{\circ} \mathrm{C}$ (at constant irradiation). Its value is in case of a monocrystalline cell usually about $-0,5 \% /{ }^{\circ} \mathrm{C}$. The cell temperature $\left(\mathrm{T}_{\text {cell }}\right)$ isn't with the ambient temperature, but it can be calculated from it and from the irradiation

$$
T_{\text {cell }}=T_{a m b}+\frac{N O C T-20^{\circ} \mathrm{C}}{800\left[\mathrm{~W} / \mathrm{m}^{2}\right]} \cdot S(2)
$$

The NOCT (Nominal Operating Cell Temperature) is a constant parameter which is the cell temperature at 800 $\mathrm{W} / \mathrm{m}^{2}$ irradiation, $20^{\circ} \mathrm{C}$ ambient (air) temperature, and 1 $\mathrm{m} / \mathrm{s}$ wind speed. Its value is usually between $42-46{ }^{\circ} \mathrm{C}$.

This is the DC power on the module output, so we have to subtract the ohmic loss of the cables between the modules and the inverter $\left(\mathrm{P}_{\text {cable }}\right)$, and multiply this by the actual efficiency of the inverter $\left(\eta_{\text {inv }}\right)$. This efficiency depends on the input voltage and power of the inverter. Its characteristics are normally similar to the following curves:

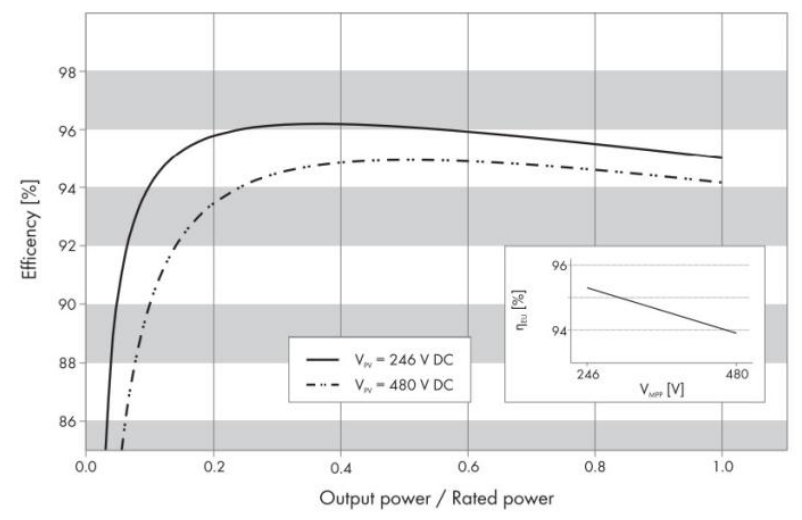

Fig. 3. SMA Sunny Mini Central 6000A inverter output power / rated power

We compared the annual energy production results calculated using this efficiency curve with the results calculated using the so called EU-efficiency. This latter is a weighted efficiency number which tries to take the inverter's loading into account during the year - see Equation (3). Of course its value depends on geographically location, meteorological conditions and the technical parameters of the system. [7]-[9]

$$
\begin{gathered}
\eta_{E U}=0,03 \cdot \eta_{5 \%}+0,06 \cdot \eta_{10 \%}+0,13 \cdot \eta_{20 \%}+0,10 \\
\eta_{30 \%} \cdot 0,48 \cdot \eta_{50 \%}+0,20 \cdot \eta_{100 \%}(3)
\end{gathered}
$$

Our results verify this, as our annual efficiency averages $\left(\eta_{\mathrm{P}-\mathrm{U}}\right)$ fairly differ from the EU-efficiency:

\begin{tabular}{|c|c|c|c|}
\hline & House roof & Wall roof & Wall facade \\
\hline $\boldsymbol{\eta}_{\mathbf{E U}}$ & $95.3 \%$ & $90.9 \%$ & $95.3 \%$ \\
\hline $\begin{array}{c}\boldsymbol{\eta}_{\text {P-U }} \text { (yearly } \\
\text { avarage) }\end{array}$ & $92.9 \%$ & $87.5 \%$ & $91.3 \%$ \\
\hline
\end{tabular}

Table 1. Weighted and calculated inverter efficiencies

The following figure shows the annual distribution of the actual inverter efficiency (hourly resolution). 


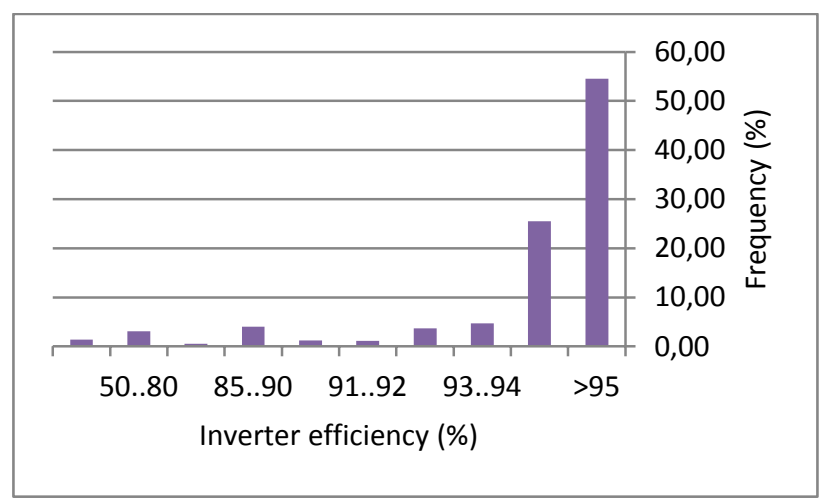

Fig. 4. Inverter efficiency distribution (\%)

\section{B. Input data}

Input data of the MATLAB script are hourly based meteorological time series, namely ambient temperature and irradiation data. The geographical location of the system (Budapest or Madrid), the PV fields (house roof, wall roof, wall facade) and the type of the modules can be chosen from the built in menu. It's also possible to set up a cooling target temperature value (in case of modulecooling).

The input irradiation data of the script are the values on $6.5^{\circ}$ and $90^{\circ}$ (vertical) tilted surfaces. These are not measured ones, but calculated from the measured horizontal irradiation. This was necessary, because global radiation on surface at an arbitrary angle cannot be calculated so easily from the global radiation on horizontal plane. If a tilted module would only get direct radiation as this is the case in the space - it wouldn't be a hard job to calculate the harnessable radiation based on the horizontal radiation. But on the earth even at clear sky the proportion of diffuse radiation is $\sim 10 \%$, and the continental climate is fairly cloudy and also the hills and mountains modify the amount of diffuse light.

A correction factor was calculated for each hour of the year in the following way: from the online database called SoDa (Solar Radiation Data) [10], queries were prepared for horizontal, vertical and $6.5^{\circ}$ tilted plane radiation time series. The data were measured in Madrid, 2005 (TMY data). The SoDa series could not be used directly for our simulation, as it doesn't contain temperature values measured parallel with the irradiation. So we composed the quotient of these time series $\left(\mathrm{S}_{6.5} / \mathrm{S}_{0}\right.$ and $\left.\mathrm{S}_{90} / \mathrm{S}_{0}\right)$ and with these hourly based correction factors we multiplied the horizontal TMY data of Madrid.

The SoDa engine is able to map the measured horizontal irradiation on arbitrary tilted surface, so we hoped that our method gives a relative good approximation. This wasn't fully supported by our results, as the annual energy production based on the original SoDa data and our corrected TMY data showed remarkable ( 10\%) difference.

\begin{tabular}{|c|c|c|}
\hline & $\mathbf{6 . 5}^{\circ}$ tilted & $\mathbf{9 0}^{\circ}$ tilted \\
\hline SoDa database & $1929 \mathrm{kWh} / \mathrm{m}^{2} /$ year & $1412 \mathrm{kWh} / \mathrm{m}^{2} /$ year \\
\hline $\begin{array}{c}\text { corrected TMY } \\
\text { database }\end{array}$ & $1748 \mathrm{kWh} / \mathrm{m}^{2} /$ year & $1266 \mathrm{kWh} / \mathrm{m}^{2} /$ year \\
\hline
\end{tabular}

Table 2. Comparison of annual global radiation on tilted surfaces

Detailed input data:

- Meteorological data
- global radiation on a surface with a given tilt angle $\left(\mathrm{W} / \mathrm{m}^{2}\right)$
- ambient (air) temperature $\left({ }^{\circ} \mathrm{C}\right)$

- Electrical parameters of the PV module

- Nominal power of the module $\left(\mathrm{W}_{\mathrm{p}}\right)$

- Temperature coeff. of voltage, current and power $\left(\% /{ }^{\circ} \mathrm{C}\right)$

- module MPP-voltage (V)

- module MPP-current (A)

○ nominal cell temperature (NOCT, ${ }^{\circ} \mathrm{C}$ )

- number of modules (pcs)

- Number of PV-strings (pcs)

- Electrical parameters of the inverter

$\circ$ nominal output power $\left(\mathrm{P}_{\mathrm{AC}}, \mathrm{W}\right)$

$\circ$ nominal input power $\left(\mathrm{P}_{\mathrm{DC}}, \mathrm{W}\right)$

$\circ$ efficiency curve of the inverter (in table format, \%)

- MPP-voltage range $\left(\mathrm{U}_{\mathrm{MPP}, \min }, \mathrm{U}_{\mathrm{MPP}, \max }\right)$

- Resistance of the DC-cable between the modules and the inverter $(\Omega)$

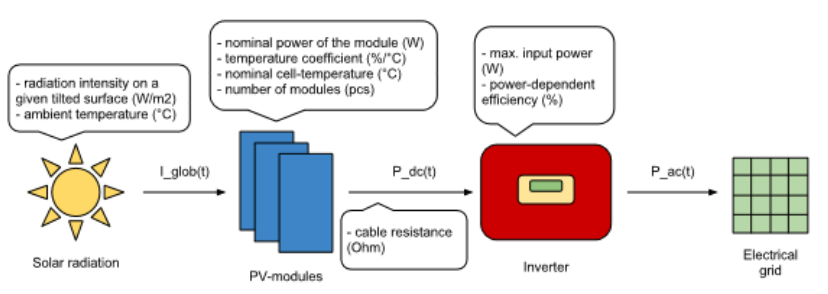

Fig. 5: Block diagram of the PV system

\section{Output data}

Output of the script can be either hourly or 6-mins based:

- AC-side energy, without module-cooling (Wh)

- $\quad$ string voltage $(\mathrm{V})$

- $\quad$ string current (A)

- amount of cooling $\left({ }^{\circ} \mathrm{C}\right)$ required to reach the maximum inverter output power (if actual power is below it)

- $\quad$ AC-side energy, in case of module cooling to a constant temperature, eg. $30^{\circ} \mathrm{C}(\mathrm{Wh})$

- power loss on the DC-cable between the modules and the inverter (Wh)

- actual efficiency of the inverter (\%)

- actual inverter loss (Wh) 


\section{Simulation results}

The yearly energy production of the $13.475 \mathrm{~kW}_{\mathrm{p}}$ system estimated by the script is $14384 \mathrm{kWh}$ in Budapest, and $19284 \mathrm{kWh}$ in Madrid. These results have been checked with several other programs (Sunny Design 1.57, EU-JRC PVGIS, PVsyst5 [12]-[14]), which supplied not so satisfactory results, there was a $10-15 \%$ difference compared to our results.

\begin{tabular}{|l|c|c|c|c|}
\hline & \multicolumn{4}{|c|}{ Annual energy production (kWh) } \\
\hline & $\begin{array}{c}\text { MATLAB } \\
\text { script }\end{array}$ & $\begin{array}{c}\text { Sunny } \\
\text { Design }\end{array}$ & EU-JRC & PVsyst5 \\
\hline House roof & 12504 & 10986 & 11200 & 11317 \\
\hline Wall roof & 2511 & 2213 & 2375 & 2403 \\
\hline Wall facade & 4269 & 3167 & 3717 & 3069 \\
\hline TOTAL & $\mathbf{1 9 2 8 4}$ & $\mathbf{1 6 3 6 6}$ & $\mathbf{1 7 2 9 2}$ & $\mathbf{1 6 7 8 9}$ \\
\hline
\end{tabular}

Table 3. Comparison of simulation results

The reason for it can be mainly that those programs calculate with different meteorological data sets (we're using one from year 2010), and that they estimate power losses not so exactly.

We also tested that the string voltages remain in the MPP voltage range of the inverters - this was fulfilled apart from 7 hours in a year, so the system is well designed.

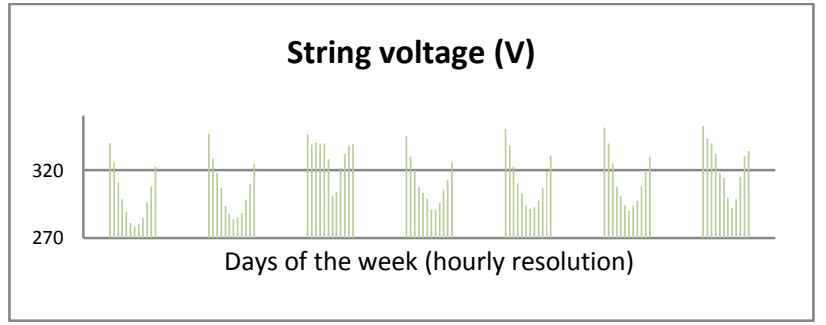

Fig. 6. String voltages in a week $\left(V_{D C}\right)$

The following graphs show the annual energy distribution in monthly base.

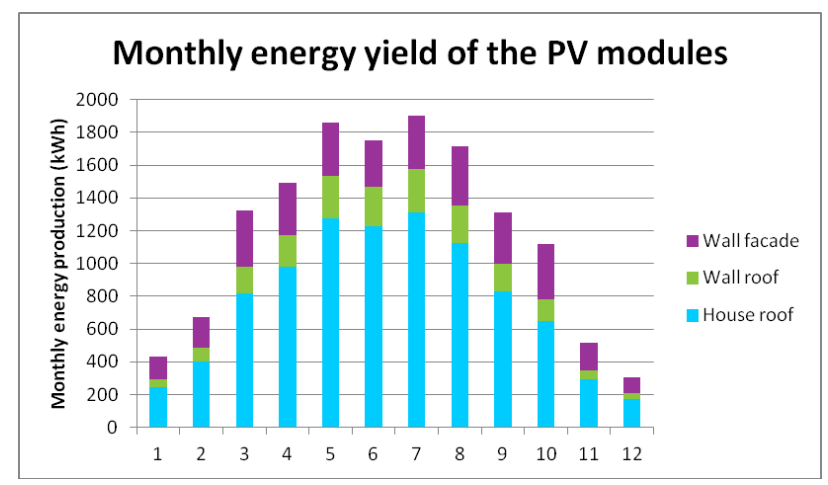

Fig. 7. PV energy production in Budapest

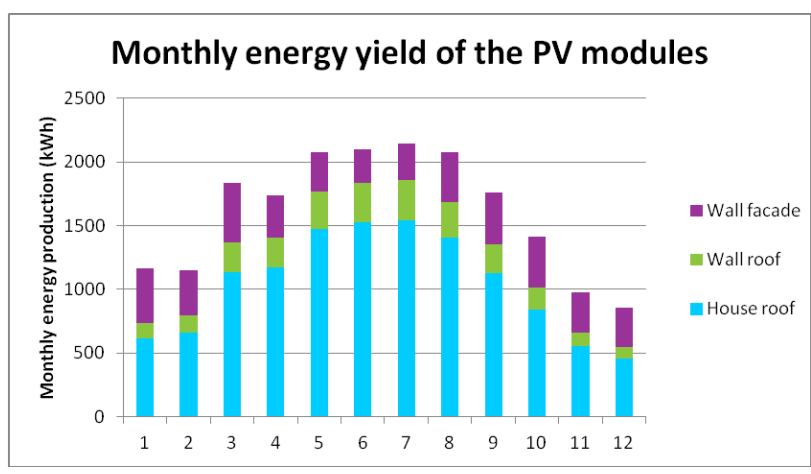

Fig. 8. PV energy production in Madrid

The figures clearly show that the vertical modules on the southern facade perform better in winter than their almost horizontal mates - thanks to the lower sun-path - and so they even a bit the annual energy distribution.

It can be desirable to know the optimal number of PV panels connected to an inverter. We use the expression 'optimal' in the following sense: we are searching an extreme point of the number of modules at that the PV array gets oversized. Oversizing the PV array doesn't necessarily mean the overloading of the inverter, because the inverter just moves out of the optimal operating point (MPP), in order to limit the input current. The effect of oversizing can be observed on the annual plus energy that one more PV module produces.

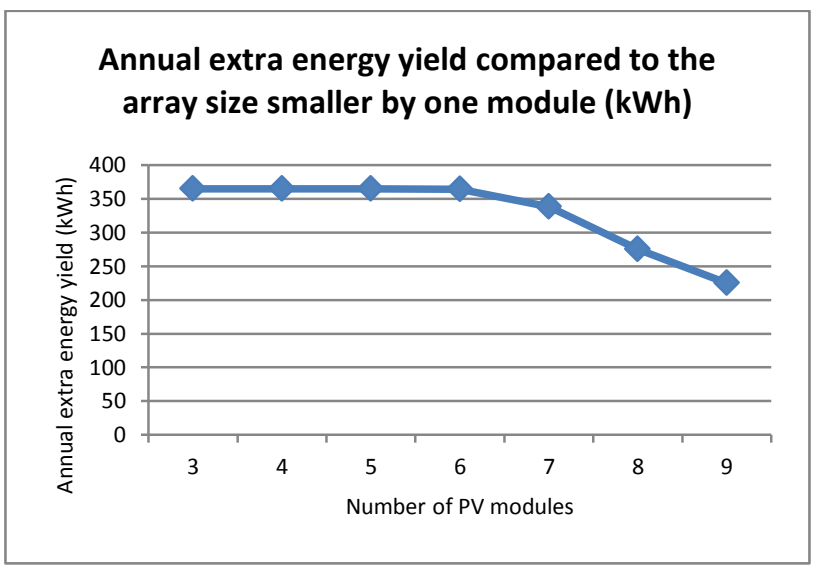

Fig. 9. Effect of oversizing the PV array compared to the inverter

Especially in summer the modules can get very hot (60$70{ }^{\circ} \mathrm{C}$ ), so it's worth looking at the option of cooling although because of the water pumps it has its own electricity demand, too. In the calculation we assumed constant $30{ }^{\circ} \mathrm{C}$ cooling target temperature. The table below shows the extra energy production due to cooling in a week and over the year. It can be concluded that the cooling effect depends not only on the tilt angle of the modules, but on the inverters, too (see house roof and wall roof, which have the same $6.5^{\circ}$ tilt angle, and still have different annual energy production values). 


\begin{tabular}{|c|c|c|c|c|}
\hline & \multicolumn{2}{|c|}{ Yearly } & \multicolumn{2}{c|}{ Weekly } \\
\hline & $\begin{array}{c}\text { energy } \\
\text { (no cooling) }\end{array}$ & $\begin{array}{c}\text { plus } \\
\text { energy }\end{array}$ & $\begin{array}{c}\text { energy } \\
\text { (no cooling) }\end{array}$ & $\begin{array}{c}\text { plus } \\
\text { energy }\end{array}$ \\
\hline $\begin{array}{c}\text { House } \\
\text { roof }\end{array}$ & $12504 \mathrm{kWh}$ & $\begin{array}{c}530 \mathrm{kWh} \\
(4.2 \%)\end{array}$ & $276 \mathrm{kWh}$ & $\begin{array}{c}19 \mathrm{kWh} \\
(7.0 \%)\end{array}$ \\
\hline Wall roof & $2511 \mathrm{kWh}$ & $\begin{array}{c}98 \mathrm{kWh} \\
(3.9 \%)\end{array}$ & $56 \mathrm{kWh}$ & $\begin{array}{c}3,5 \mathrm{kWh} \\
(6.4 \%)\end{array}$ \\
\hline $\begin{array}{c}\text { Wall } \\
\text { facade }\end{array}$ & $4268 \mathrm{kWh}$ & $\begin{array}{c}87 \mathrm{kWh} \\
(2.0 \%)\end{array}$ & $95 \mathrm{kWh}$ & $\begin{array}{c}4,5 \mathrm{kWh} \\
(4.8 \%)\end{array}$ \\
\hline TOTAL & $\mathbf{1 9 2 8 4} \mathbf{k W h}$ & $\begin{array}{c}\mathbf{7 1 5} \mathbf{k W h} \\
(\mathbf{3 . 7} \%)\end{array}$ & $\mathbf{4 2 7} \mathbf{k W h}$ & $\begin{array}{c}\mathbf{2 7} \mathbf{k W h} \\
(\mathbf{6 . 3} \%)\end{array}$ \\
\hline
\end{tabular}

Table 4. Yearly and weekly energy produced with and without cooling (Madrid)

\section{Comparing yields of thin-film PVs}

The energy production of three thin-film PV modules (Kaneka, NexPower, Sharp) were also compared, which can be suitable for the southern wall facade, as they utilize diffuse light better than crystalline cells, and the vertical PV field on the wall gets much more diffuse light than those on the roofs.

The comparison was made among the following modules: Kaneka U-EA 120 [15], Nexpower NT 150 [16], Sharp NA 128 [17], the simulation location was Madrid. The annual specific energy results $\left(\mathrm{kWh} / \mathrm{kW}_{\mathrm{p}}\right)$ can be seen on the figure below - they markedly don't differ very much.

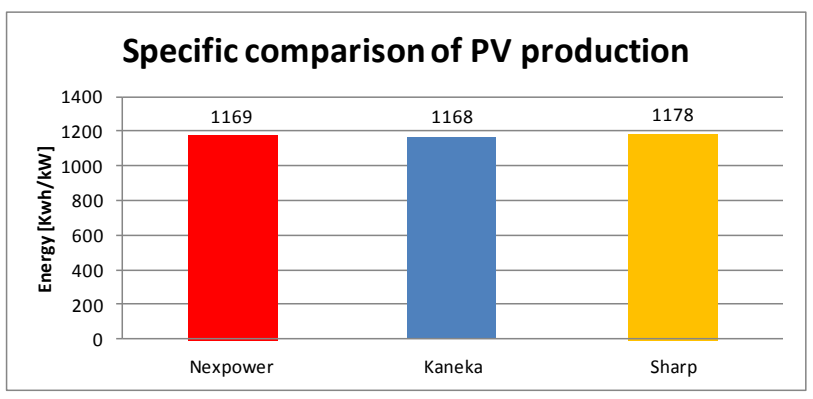

Fig. 10. Specific energy of various thin film PV modules

The simulation of thin film panels is not fully correct yet, because the technological difference from the crystalline modules wasn't taken into account - only the electrical parameters of the cell: voltages, currents and temperature coefficient. But the fact that thin film modules harness diffuse light better, cannot be observed on the results at this stage of the project.

\section{Conclusions}

We found that the annual energy yield in Madrid is 34\% more than in Budapest, while the annual irradiation on the modules is $37.3 \%$ more than in Budapest. The difference is mainly due to the vertical PV field, which performs better in Budapest because of the lower sun-path.

It's also obvious that it's worthy to oversize the inverter by several ten percent, btw. that with a realistic cooling (target temp. $30^{\circ} \mathrm{C}$ ) we get some extra annual yield: 1.6$3.2 \%$ in Budapest, and 2.0-4.2\% in Madrid.

We can conclude based on our inverter-efficiency results that the European efficiency of the inverter overestimates by $2.5-4 \%$ the efficiency in annual average - depending of the type of the PV modules, the inverter and the module tilt angle.

Our long-term goal is to develop an energy management system that includes load estimation and takes also the actual electricity prices into account. We'd also like to perform a cooling optimisation, which means: what is the temperature value to which if we cool down the modules, the benefit of extra profit would be maximal in contrast to the energy demand of cooling. Additionally we'll analyse the possibility of the estimation of energy production based on the spectral response of the solar cell.

\section{References}

[1] Solar Decathlon Europe http://www.sdeurope.org/

[2] BME Odooproject http://odooproject.com/

[3] MATLAB

http://www.mathworks.com/products/matlab/index.html

[4] Korax Solar

http://www.koraxsolar.hu/

[5] SMA

http://www.sma.de/en

[6] D. Horváth, „Family home electricity supply by mini size power station" (Elektrotechnika 11/2009), paper in Hungarian. www.mee.hu/files/ET/2009/ET_2009_11.pdf

[7] F. Kaeser, Ch. Liebi and Ch. Beutler Haeberlin: "Results of Recent Performance and Reliability Tests of the Most Popular Inverters for Grid Connected PV Systems in Switzerland" (2005, BFH-TI)

http://labs.ti.bfh.ch/fileadmin/user_upload/lab1/pv/Inverter_Tes ts Nice 95-A4.pdf

[8] Benoit Bletterie et al.: "Redefiniton of the European Efficiency - Finding the compromise between simplicity and accuracy" (2008, ZHAW) https://home.zhaw.ch/ bauf/pv/papers/2008_EUPVSEC_Invert er_EFF_4CO_2_5.pdf

[9] J. Adelstein, K. Boyle et al. B. Marion: "Performance Parameters for Grid-Connected PV Systems" (2005, NREL) http://www.nrel.gov/docs/fy05osti/37358.pdf

[10] SoDA solar radiation database

http://www.soda-

is.com/eng/services/services_radiation_free_eng.php

[11] HelioClim

http://www.sodais.com/eng/helioclim/helioclim_principle_decomposition.html 
[12] SMA Sunny Design (software)

http://www.sma.de/en/products/software/sunny-design.html

[13] Photovoltaic Geographical Information System (EU-JRC

PVGIS)

http://re.jrc.ec.europa.eu/pvgis/apps4/pvest.php

[14] PVsyst - Studies, sizing and simulations

http://www.pvsyst.com/en/download

[15] Kaneka U-EA 120 (PV module datasheet)

http://www.kaneka-solar.com/products/pdf/U-EA.pdf

[16] Nexpower-NT 150 (PV module datasheet) http://www.nexpw.com/images/datasheet/DDS10011 NT-Series150AX EN P.pdf

[17] Sharp NA 128 (PV module datasheet)

http://www.solardesigntool.com/components/module-panelsolar/Sharp/NA-V128h1/specification-data-sheet.html

[18] Gábor Ádám, Kristóf Baksai-Szabó: "Energy production estimating of photovoltaic systems". BUTE Student's Scientific Circle conference, 2011, paper in Hungarian.

[19] Gábor Ádám, Kristóf Baksai-Szabó and Péter Kiss: "Simulation of photovoltaic system energy production" (Elektrotechnika 12/2011), paper in Hungarian. http://www.mee.hu/sites/default/files/u9/et2011-12.pdf 